\title{
The Literary Motif of Cush in the Old Testament
}

\author{
Marta Høyland LaViK (STaVanger UNiVERSity HosPital, \\ Stavanger, NorWay AND STEllenbosch University, SOUTH \\ AFRICA)
}

\begin{abstract}
There are 56 references to Cush in the Old Testament and these occur in all the three main corpuses of the Hebrew Bible namely the Law, the Prophets and the Writings. Traditional historical-critical scholarship has not showed great interest in the Old Testament texts about Cush. However, the Nigerian biblical scholar David Tuesday Adamo has through his many contributions about the Cush texts made the guild observant of what can be labelled an African presence in the Old Testament given that Cush is applied as a literary motif in the Old Testament. Following a presentation of the Cush texts in the Old Testament, this paper examines how the literary motif of Cush functions in the text, taking Isaiah 18 as a representative example. ${ }^{1}$
\end{abstract}

KEYWORDS: Cush, Old Testament, Isaiah 18, Adamo, Africa, African

\section{A INTRODUCTION}

Geographically, the Old Testament texts are for obvious reasons centred round Israel/Judah and the Mediterranean. However, more distant peoples and nations are mentioned also in the Old Testament. One of these nations is the African nation of Cush, which historically was located south of Egypt in today's southern Egypt and northern Sudan, and which reigned over Egypt for approximately one hundred years in ancient times (744-656 B.C.).

There are two main ways in which the Old Testament Cush texts can be studied - with regards to how they relate either to ancient historical circumstances and archaeological discoveries or to the literary biblical contexts in which they are situated. If European and American scholars working within the traditional historical-critical understanding have paid attention at all to the Cush texts, they have engaged mainly with questions of history, archaeology and geography ${ }^{2}$ and have interpreted the texts from a hermeneutical perspective

* Submitted: 28/04/2021; peer-reviewed: 15/07/2021; accepted: 30/07/2021. Marta Høyland Lavik, "The Literary Motif of Cush in the Old Testament," Old Testament Essays 34 no. 2 (2021): 460 - 473. DOI: https://doi.org/10.17159/23123621/2021/v34n2a9.

2 For references, see Marta Høyland Lavik, A People Tall and Smooth-skinned: The Rhetoric of Isaiah 18 (Supplements to Vetus Testamentum 112; Leiden: Brill, 2007), 16-20. 
influenced by their time. ${ }^{3}$ David Adamo and the Norwegian Old Testament scholar Knut Holter have been advocates of African readings of the Cush texts and of reading these texts in dialogue between African and European scholars. ${ }^{4}$

The present contribution is centred round how Cush is used as a literary motif in the Old Testament in general and in Isa 18 in particular. This is more thoroughly elaborated on in my doctoral thesis published in 2007, A people tall and smooth-skinned: The rhetoric of Isaiah 18. Building on the findings from my thesis and subsequent articles, ${ }^{5}$ the next section will briefly present the Old Testament Cush texts, where they are to be found, and what in my interpretation they express about Cush and Cushites. Subsequently and based on an analysis of the rhetoric of the text, I consider the possible literary functions of the motif of Cush in the Old Testament, exemplified by Isa 18.

\section{B THE CUSH TEXTS OF THE OLD TESTAMENT}

The honouree of the present volume of Old Testament Essay, the Nigerian biblical scholar David Tuesday Adamo, is known for his profiled publications on the Cush texts of the Old Testament. He wrote his $\mathrm{PhD}$ thesis about all the Cush passages of the Old Testament ${ }^{6}$ and in a number of subsequent articles, ${ }^{7}$ he has considered how Africa - and in particular the African nation Cush influenced the life of ancient Israel. ${ }^{8}$ This stands in contrast to how the African continent has been portrayed both within and outside biblical scholarship over

3 Knut Holter, “'A Negro, Naturally a Slave': An Aspect of the Portrayal of Africans in Colonial Old Testament Interpretation," Old Testament Essays 21/2 (2008): 373-382.

4 Knut Holter, "Does a Dialogue between Africa and Europe Make Sense?" in African and European Readers of the Bible in Dialogue (ed. Hans de Wit and Gerald O. West; Leiden: Brill, 2008), 69-80. P. Lokel, "Previously Unstoried Lives: The Case of Old Testament Cush and Its Relevance to Africa," Old Testament Essays 19/2 (2006a): 525-537.

5 Marta Høyland Lavik, "Afrika i Det gamle testamentet," in Med Kristus til jordens ender: Festskrift til Tormod Engelsviken (ed. K.O. Sannes; Trondheim: Tapir akademisk forlag, 2008), 173-181; “"På den tid skal dei koma med gåver til Herren over hærskarane, frå det høgvaksne glinsande folket': Afrikanske og afrikanskamerikanske tolkingar av GT-tekstar om Kusj," in Jerusalem, Samaria og jordens ender: Bibeltolkninger tilegnet Magnar Kartveit, 65 år, 7. Oktober 2011 (ed. K. Holter and J. Ådna; Trondheim: Tapir akademisk forlag, 2011), 155-169; "Are the Kushites Disparaged in Isaiah 18? Kush Applied as a Literary Motif in the Hebrew Bible," $\begin{array}{lllll}\text { Journal of Hebrew } & \text { (2019): 17-43, }\end{array}$ http://www.jhsonline.org/Articles/article_253.pdf.

6 David T. Adamo, "The Place of Africa and Africans in the Old Testament and Its Environment" (PhD thesis, Baylor University: Waco, 1986).

7 For references, see M. Høyland, "An African Presence in the OT? David Tuesday Adamo's Interpretation of the OT Cush Passages," Old Testament Essays 11/1 (1998): 50-58; Lavik, A People Tall and Smooth-skinned, 239.

8 Adamo, "The Place of Africa and Africans in the Old Testament." 
the last centuries. ${ }^{9}$ Clearly, Adamo's work has had an impact on the development of an African biblical hermeneutics; but what are the Old Testament Cush texts?

There are 56 references to Cush and Cushites in the Old Testament. Whereas the term כוש occurs 30 times, כושי occurs 26 times and the 56 references are found in all three parts of the canon-the Law, the Prophets and the Writings. ${ }^{10}$ Whether or not all 56 instances refer to an African location has been disputed ${ }^{11}$ but Adamo identifies an African location for all references to Cush in the Old Testament: "Everywhere the word 'Cush' is used with a clear cut identification, it refers to Africa." 12 Adamo also suggests that the Hebrew word כוש be rendered Africa in modern translations of the Bible. ${ }^{13}$ A presentation of the 56 references to Cush has earlier been given in works published by Holter, Sadler, Lokel and me (in Norwegian in 2008 and 2011 and in English in 2007 and 2019). ${ }^{14}$ The following is a condensation of these surveys.

In the Law, there are six references to Cush, four of which appear in Genesis (Gen 2:13; 10:6, 7, 8) and two in Numbers (Num 12:1, 1). When the motif of Cush appears in the Pentateuch it has to do with either places or people. In the creation story, Cush is located as one of the countries around which the second river of Eden flows (Gen 2:13): "The name of the second river is Gihon; it winds through the entire land of Cush." By mentioning Cush here, Africa is

9 Kevin Burrell, Cushites in the Hebrew Bible: Negotiating Ethnic Identity in the Past and Present (Biblical Interpretation Series 181; Leiden: Brill, 2020).

10 Abraham Even-Shoshan, A New Concordance of the Bible (Jerusalem: KiryatSepher Publishing House [Hebrew], 1983), 527.

11 S. Hidal, "The Land of Cush in the Old Testament," Svensk exegetisk årsbok 41-42 (1977): 97-106.

12 David T. Adamo, "Ethiopia in the Bible," African Christian Studies 8 (1992): 5164 (51).

13 For a debate on whether or not the Hebrew term כוש should be translated Africa, see the discussions in Knut Holter, "Should Old Testament Cush Be Rendered 'Africa'?," in Yahweh in Africa: Essays on Africa and the Old Testament (ed. Knut Holter; New York: Peter Lang, 2000), 107-114; Willie Van Heerden, "Finding Africa in the Old Testament: Some Hermeneutical and Methodological Considerations," Old Testament Essays 19/2 (2006): 500-524.

14 Knut Holter, "Africa in the Old Testament" in Yahweh in Africa: Essays on Africa and the Old Testament (ed. Knut Holter; New York: Peter Lang, 2000), 93-106; Rodney S. Sadler, Can a Cushite Change His Skin? An Examination of Race, Ethnicity, and Othering in the Hebrew Bible (Journal for the Study of the Old Testament Supplement Series 425; New York: T \& T Clark, 2005); P. Lokel, "The Importance and Challenges of Finding Africa in the Old Testament: The Case of the Cush Texts" (PhD thesis, Pretoria: University of South Africa), 2006; Marta Høyland Lavik ${ }_{2}$ "Afrika i Det gamle testamentet;" "“På den tid skal dei koma med gåver til Herren over hærskarane"; $A$ People Tall and Smooth-skinned; "Are the Kushites Disparaged in Isaiah 18?" 
included in the world map reflected in Gen 2:13. ${ }^{15}$ In Gen 10:6, 7, 8 and in Num 12 , the lens zooms in and refers to individuals. In the genealogy of Gen 10, Cush is used as a personal name together with Egypt, Put and Canaan in the list of the descendants of Ham. Cush is mentioned first in Gen 10:6 probably due to a geographical orientation starting from the far south. ${ }^{16}$ One of Cush's offspring is Nimrod who is described in Gen 10:8 as "the first on earth to become a mighty warrior." His name is then related with Babylonia (v. 10) and Assyria (v. 11). It has been proposed that in the Table of Nations Cush is an eponym for the Kassites in Mesopotamia. ${ }^{17}$ Further, verses $10-12$ list several places and cities that this son of Cush established. Num 12:1 says twice that Moses is married to a woman of Cush: "While they were at Hazeroth, Miriam and Aaron spoke against Moses because of the Cushite woman whom he had married (for he had indeed married a Cushite woman)." Explanations to why this choice is criticised by Miriam and Aaron have been offered. ${ }^{18}$ Seen together, the references to Cush and Cushites in the Law function to place Cush on the ancient Israelites' geographical and mental map.

In the Prophets, Cush is mentioned in relation to both its reputation as a powerful potential alliance partner and individuals playing a role in the history of the people of YHWH. The former prophets have eight references to Cush (2 Sam 18:21 (x2), 22, 23, 31, 32 (x2); 2 Kgs 19:9), whereas the latter prophets have twenty-five references (Isa 11:1; 18:1; 20:3, 4, 5; 37:9; 43:3; 45:14; Jer 13:23; 36:14; 38:7, 10, 12; 39:16; 46:9; Ezek 29:10; 30:4, 5, 9; 38:5; Amos 9:7; Nah $3: 9 ;$ Zeph $1: 1 ; 2: 12 ; 3: 10)$. The eight references in the former prophets are found in two different narratives, both alluding to the military capacity of the Cushites. The first narrative (2 Sam 18) depicts a Cushite officer in King David's army (vv. 21-33) who reports Absalom's death to the king (vv. 32-33): "The king said to the Cushite, "Is it well with the young man Absalom?" The Cushite answered, "May the enemies of my lord the king, and all who rise up to do you

15 Hidal, "The Land of Cush in the Old Testament," 97-106; Holter, "Africa in the Old Testament," 101; Terje Stordalen, Echoes of Eden: Genesis 2-3 and Symbolism of the Eden Garden in Biblical Hebrew Literature (Contributions to Biblical Exegesis and Theology 25; Leuven: Peeters, 2000), 279-281.

16 David T. Adamo, "The Table of Nations Reconsidered in African Perspective (Genesis 10)," Journal of African Religion and Philosophy 2 (1993): 138-143.

17 See E.A. Speiser, "The Rivers of Paradise," in Festschrift Johannes Friedrich zum 65. Geburtstag am 27. August 1958 gewidmet (ed. R. von Kienle and A. Moortgat et al.; Heidelberg: Carl Winter Universitätsverlag, 1959), 473-485 (475); Jon D. Levenson, Sinai and Zion: An Entry into the Jewish Bible (Minneapolis: Winston Press, 1985), 131.

18 David T. Adamo, "The African Wife of Moses: An Examination of Numbers 12:19," Africa Theological Journal 18 (1989): 230-237; Daniel J. Hays, "The Cushites: A Black Nation in Ancient History," Bibliotheca sacra 153 (1996): 270-280; Holter, "Africa in the Old Testament," 101. 
harm, be like that young man." The king was deeply moved, and went up to the chamber over the gate, and wept; and as he went, he said, "O my son Absalom, my son, my son Absalom! Would I had died instead of you, O Absalom, my son, my son!" The other narrative (2 Kgs 19) gives the Cushite king Taharqo a supporting role in the deliverance of Jerusalem (v. 9). Both narratives portray the two individuals from Cush as having important roles in society and implicitly in relation to the people of $\mathrm{YHWH}^{19}$

In the twenty-five references to Cush in the latter prophets, the Cushites are featured in various ways. In Isa 18 and Jer 13:23, the Cushites' bodies are described. In a proverb-like manner, Jer 13:23 uses the skin colour of the Cushites and the spots of the leopard to say something about the persistence of the people of YHWH: "Can the Cushites change their skin or leopards their spots? Then also you can do good who are accustomed to do evil" (Jer 13:23). In Isa 43:3 and 45:14, the wealth of Cush is alluded to (45:14):

"Thus says the Lord:

The wealth of Egypt and the merchandise of Cush, and the Sabeans, tall of stature,

shall come over to you and be yours,

they shall follow you;

they shall come over in chains and bow down to you.

They will make supplication to you, saying,

"God is with you alone, and there is no other; there is no god besides him."

In Isa 20, Cush is described as an attractive alliance partner against which YHWH's people are warned. Allusion to the Cushites' military reputation is seen in lists: "Cush was her strength, Egypt too, and that without limit; Put and the Libyans were her helpers" (Nah 3:9; see also Ezek 38:5) and in the narrative about the Cushite Ebed-Melech (Jer 38-39). Ebed-Melech is portrayed as a creative officer who plays an important role in rescuing the prophet who is thrown into the king's cistern to die. Thus, this narrative puts a Cushite in a central position in relation to both the prophet and royalty. In Amos 9:7, the exodus from Egypt of YHWH's people is compared to similar experiences from other peoples and both Cush and Israel in this text are likened to each other: "Are you not like the Cushites to me, O people of Israel? says the Lord. Did I not bring Israel up from the land of Egypt, and the Philistines from Caphtor and the Arameans from Kir?" (Amos 9:7). ${ }^{20}$ In Ezek 29:10, Cush is seen as a limit of the

19 Cf. Henry T. Aubin, The Rescue of Jerusalem: The Alliance of Hebrews and Africans in 701 BC (Toronto: Anchor Canada, 2003).

20 David T. Adamo, "Amos 9:7-8 in an African Perspective," Orita 24 (1992a): 7684; R. Smith, "A New Perspective on Amos 9:7a," Journal of the Interdenominational Theological Center 22 (1994): 36-47; Knut Holter, "Is Israel Worth More to God than Cush? An Interpretation of Amos 9:7," in Yahweh in Africa: Essays on Africa and the Old Testament (ed. Knut Holter; New York: Peter Lang, 2000), 115-125. 
borders of the known world and in Zeph 2:4-15, 12, Cush can be interpreted as representing the far south in the prophet's orientation. In the opening verse of Zeph (1:1), the prophet is introduced as the son of Cushi and whether or not this points to an African origin is debated. ${ }^{21} \mathrm{Cush}$ is mentioned also in the context of eschatological salvation (Isa 11:11-12; 18:7; Zeph 3:10): "From beyond the rivers of Cush my suppliants, my scattered ones, shall bring my offering" (Zeph $3: 10)$.

In the Writings, Cush and Cushites are mentioned seventeen times. The Psalms have three references $(7: 1 ; 68: 32 ; 87: 4)$, the Book of Job has one (28:19), in Esther there are two $(1: 1 ; 8: 9)$, in Daniel there is one (11:43), 1 Chronicles has three references $(1: 8,9,10)$ whereas there are seven in 2 Chronicles $(12: 3 ; 14: 8$, 11, 12 (x2); 16:8; 21:16). Psalm 68:32 [ET: 68:31] probably alludes to bringing tribute to YHWH in Jerusalem: "Envoys will come from Egypt; Cush will quickly stretch out her hands to God." Psalm 87:4 also connects Cush to Zion by saying: "I will mention Rahab and Babylon among those who know $\mathrm{Me}-$ along with Philistia, Tyre, and Cush - when I say, 'This one was born in Zion." Job 28:19 mentions the valuable chrysolite of Cush, and alludes in this way to the wealth of Cush. In Esth 1:1; 8:9, Cush is referred to as the south-western border of the known world: "This happened in the days of Ahasuerus, the same Ahasuerus who ruled over one hundred twenty-seven provinces from India to Cush" (Esth 1:1). In Dan 11:43, Cushites are mentioned in the context of wealth and riches of Egypt. The holy war rhetoric in the narrative of 2 Chron14:9-15 also relates Cush to military abilities: "Now Zerah the Cushite came out against them with an army of a million men and 300 chariots, and he came to Mareshah" (v. 9).

This survey shows that the motif, Cush, is mentioned in the three main parts of the Hebrew Bible and within different genres. The motif is in the Old Testament applied in a two-fold way, literal and non-literal. Literally, Cush is the ancient African nation which was located south of Egypt. Non-literally, the Cush alludes to this nation's military abilities, abundance, wealth, remoteness and relation to Zion in eschatological times. The portrayal of Cush and Cushites is quite consistent and positive throughout the Old Testament. ${ }^{22}$ However, this mostly approving portrayal can be explained historically or literarily. Historically, the climax in the history of Cush is close in time to when the Old Testament came into being and what is said about Cush and Cushites in the Old

21 Cf. Roger W. Anderson, "Zephaniah ben Cushi and Cush of Benjamin," in The Pitcher is Broken. Memorial Essays for Gösta W. Ahlström (ed. S.W. Holloway and L.K. Handy; Sheffield: Sheffield Academic Press, 1995), 45-70; Gene Rice, "The African Roots of the Prophet Zephaniah," The Journal of Religious Thought 36 (1979): 21-31; David T. Adamo, "The Black Prophet in the Hebrew Bible," Journal of Arabic and Religious Studies 4 (1987): 1-8.

22 Aubin, The Rescue of Jerusalem, 165; Lavik, "Are the Kushites Disparaged in Isaiah 18?" 
Testament is most likely informed and influenced by the reputation Cush had as a great power in ancient times. Literarily, the motif of Cush is applied with a purpose, that is, the Old Testament texts use the motif to communicate a specific message to the ancient Israelite/Judean audience.

\section{THE FUNCTION OF THE LITERARY MOTIF OF CUSH - ISA 18 AS AN EXAMPLE}

As the Old Testament originated in time and history, it can be investigated based on its references to history, archaeology, geography and etcetera. At the same time, the biblical texts are literary documents which can be studied according to how they are shaped rhetorically - in order to pass on specific messages to the ancient audience, the Israelites/Judeans. In my view, when Cush is mentioned in the Old Testament, this is done to convey a message to the ancient audience. This will be further explicated in the following, using Isa 18 as an example.

Isaiah 18 is the Old Testament text which describes the Cushites and their land most thoroughly. Two major lines can be seen in the history of interpretation of this text. First, when commentators come across the word כוש, most of them focus on the historical and geographical background of Cush and not on how Cush functions as a literary motif. ${ }^{23}$ Second, most commentators interpret Isa 18 as a message of judgement against a foreign nation-Assyria, Cush or Egypt and Cush. A few scholars suggests Judah ${ }^{24}$ whereas a few others are hesitant to suggest a particular nation. ${ }^{25}$ The diverging scholarly interpretations all depart from the understanding of Isa 18:5-6. These verses are indefinite about who is to be disparaged - as the doom is delivered in metaphorical language of cutting off the shoots of a vine. Almost every scholarly solution presupposes that Isa 18 refers to political alliances in the eighth century B.C. Based on a literary reading of Isa 18, this article proposes a solution to the problem of which nation is being judged. ${ }^{26}$

As the scenes shift from strophe to strophe in Isa 18, this and other features in the text have confused exegetes over the years. ${ }^{27}$ "[ [...T]he many details of the text clouded by lexical uncertainties have caused scholars to disagree on the specific ways in which Isa. 18 deals with Kush and how

\footnotetext{
23 Lavik, A People Tall and Smooth-skinned, 16-17.

24 Cf. Ibid., 182, for references.

25 Ibid., 183-184.

26 Lavik, A People Tall and Smooth-skinned.

27 Brevard S. Childs, Isaiah and the Assyrian Crisis (Studies in Biblical Theology, Second Series 3; London: SCM Press, 1967), 45; Walter Brueggemann, Isaiah 1-39 (Louisville: Westminster John Knox Press, 1998), 152; Aubin, The Rescue of Jerusalem, 228.
} 
the prophecy is connected to the people of Israel or Judah." 28 On a redactional level, verse 7 is regarded by many scholars as a later addition. ${ }^{29}$ The present article holds that the different scenes in Isa 18 are presented deliberately in this way to lure the audience and that the scenes rhetorically cohere in the text's final form. ${ }^{30}$

Verse 1 opens with a הוי, "Ah!," an exclamation about the land along the rivers of Cush. This is followed by verse 2 in which messengers are said to travel over the waters and which also describes the land and people of Cush. In verse 3 , there is a change in perspective as "all" who live on earth are urged to be attentive when a banner will be raised and horns blown. The scene changes again in verse 4 where YHWH is the only character who watches intensely and calmly from his dwelling place. In verses 5-6, the scene is the vineyard, where "he" cuts off the quivering tendrils to which the vine attaches itself in order to climb. Verse 7 repeats much of verse 2, but in addition to what is already said about Cush, verse 7 relates the Cushites to YHWH Sebaoth on Mount Zion. In the following, the text of Isa 18 is presented in my own translation: ${ }^{31}$
v. 1a Ah! land of buzzing wings
v. $1 \mathrm{~b}$ from along the rivers of Cush,
v. $2 \mathrm{a} \alpha$ sending envoys by sea
v. $2 \mathrm{a} \beta$ and in vessels of paper-reed over the waters.
v. 2a $\gamma$ Go, swift messengers
v. $2 \mathrm{a} \delta$ to a nation tall and smooth-skinned,
v. $2 \mathrm{a} \varepsilon$ to a people feared from that day and onwards,
v. $2 b \alpha$ [to] a nation line upon line and down-treading,
v. $2 \mathrm{~b} \beta$ whose land rivers cut through.
v. 3a All who dwell in the world,
v. $3 a \beta$ and who inhabit the earth,
v. $3 b \alpha$ when a standard is raised [on the] mountains, you shall see,
v. $3 b \beta$ and when a horn is blown, you shall hear.
v. $4 \mathrm{a} \alpha$ For thus says YHWH to me:
v. $4 \mathrm{a} \beta$ I will be quiet and gaze in my dwelling place
v. $4 \mathrm{~b} \alpha$ like glowing heat of [the] light,

28 Csaba Balogh, The Stele of YHWH in Egypt: The Prophecies of Isaiah 18-20 Concerning Egypt and Kush (Oudtestamentische Studien 60; Leiden: Brill, 2011), 139.

29 Paul M. Cook, A Sign and a Wonder: The Redactional Formation of Isaiah 18-20 (Supplements to Vetus Testamentum 147; Leiden: Brill 2011), 49-79; J. Lee, A Redactional Study of the Book of Isaiah 13-23 (Oxford: Oxford University Press, 2018), 1, 67-68; Lavik, A People Tall and Smooth-skinned, 212-213.

${ }^{30}$ Lavik, "Are the Kushites Disparaged in Isaiah 18?," 40-41.

31 For textual critical discussions, see the first sections to every strophe in Lavik, $A$ People Tall and Smooth-skinned, 2. 


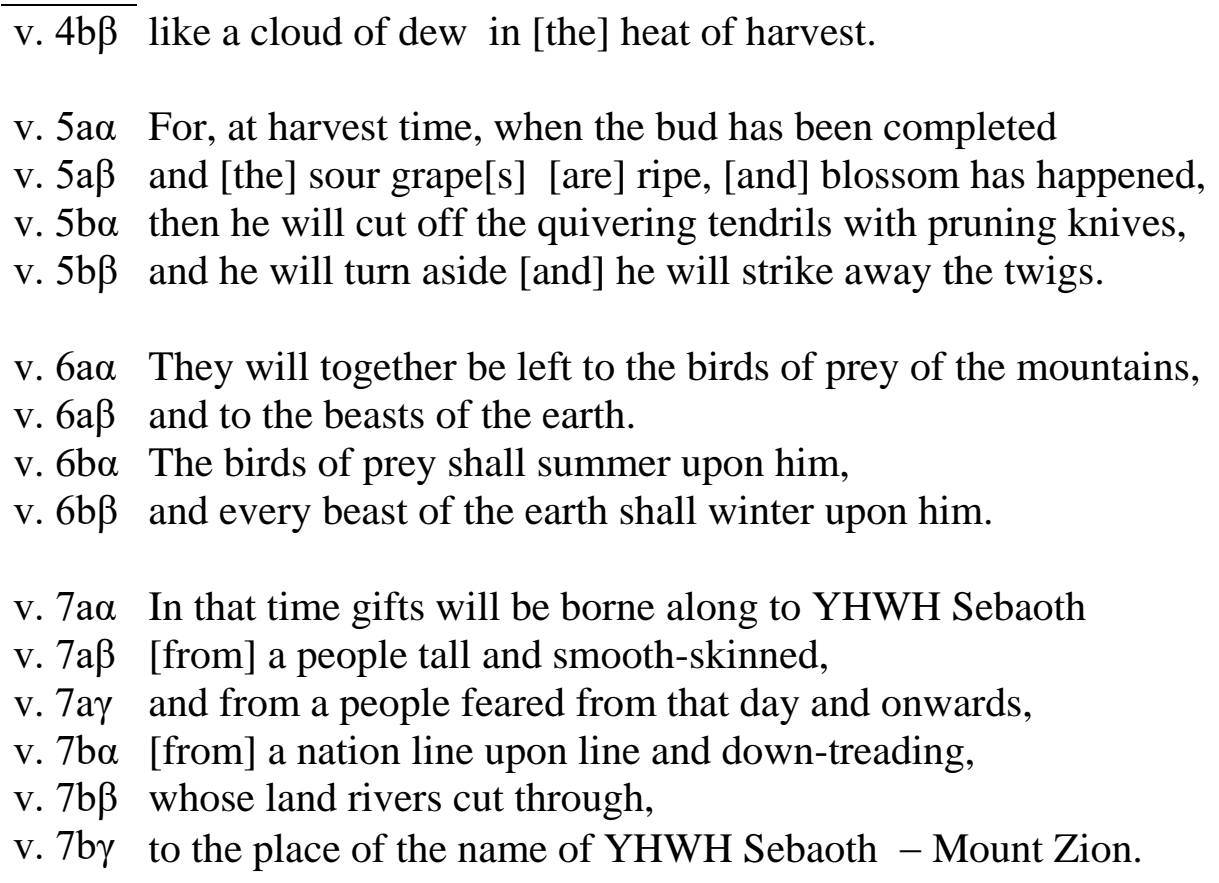

Isaiah 18 belongs to a group of texts about the foreign nations, Isa $13-23 .^{32} \mathrm{In}$ most of these texts, the foreign nation is disparaged, but in my view this is not the case with Isa $18 .{ }^{33}$ Furthermore, in Isa 18 there is a cry against a foreign nation, Cush, but what first seems to be a message of judgement upon the Cushites (vv. 1-2) reveals itself, in my interpretation, as being meant for another (vv. 5-6). If we look at the rhetorical shape of the text as a whole, it becomes clear that what seems to be randomly-put-together snapshots go well together when verses 5-6 are understood and the following discussion will elaborate on this.

Despite the sudden shifts in Isa 18, the text can be read as an example of persuasive artistry. ${ }^{34}$ In my view, the composition or artistry of a text on the one hand and its persuasiveness on the other hand are two sides of the same coin. The enigmatic way in which Isa 18 is designed has a purpose, but the inner logic is comprehended only when one realises whom the target of the metaphorical language of verses 5-6 is. As already stated, most scholars suggest that a foreign nation such as Assyria or Egypt/Cush is the target of this imaginative language. ${ }^{35}$ My claim that the judgement of Isa 18:5-6 is directed towards the people of

\footnotetext{
32 For a recent redactional study of this group of texts, see Lee, A Redactional Study of the Book of Isaiah 13-23.

33 Lavik, A People Tall and Smooth-skinned; Lavik, "Are the Kushites Disparaged in Isaiah $18 ? "$

34 The terminology is taken from Duane F. Watson, ed., Persuasive Artistry: Studies in New Testament Rhetoric in Honor of George A. Kennedy (Journal for the Study of the New Testament Supplement Series 50; Sheffield: Sheffield Academic Press, 1991). 35 For references, see Lavik, A People Tall and Smooth-skinned, 179-185.
} 
YHWH is supported only by a few scholars. ${ }^{36}$ However, the motif of vineyard is commonly applied as a metaphor for the people of YHWH throughout the Old Testament and I see no reason why it should not be the case in Isa $18 .{ }^{37}$ In my interpretation, the message of Isa 18 is: Before the potential result of an alliance with the Cushites is achieved (before the vine blossom has come to an end, v. 5), Judah's plans for aligning herself to another power will be stopped (the tendrils and twigs will be thrown away and destroyed, vv. 5-6). The calmness of YHWH (v. 4) is a pattern for the Judeans to follow and stands in sharp contrast to the activity between Judah and Cush as described through the messengers travelling back and forth (v. 2). Judah should take note (v. 3), as YHWH is not relaxed but follows the eager activity from his dwelling place with intense concentration, like "glowing heat" which makes the air vibrate (v. 4). If the Judeans seek human help before divine help (vv. 1-2), YHWH's support will be withdrawn just as the morning dew disappears in the morning (v. 4). If the audience thought the Cushites were in trouble by the הוי which was pronounced over them (v. 1), they suddenly understand that they are the target of the judgement when they hear the message of verses 5-6 about the cutting down of the vineyard. This way of ensnaring the audience to think a message is targeted at another is an example of rhetoric of entrapment. ${ }^{38}$ Such rhetoric is not unfamiliar to the Old Testament, for instance, the story of 2 Sam 12:1-15 where King David judges himself: "Then David's anger was greatly kindled against the man. He said to Nathan, "As the Lord lives, the man who has done this deserves to die; he shall restore the lamb fourfold, because he did this thing, and because he had no pity." Nathan said to David, "You are the man!" (2 Sam 12:5-7).

If we go back to the motif of Cush, how does it function in Isaiah 18 ? The portrayal of Cush and Cushites in Isa 18 gathers many of the Old Testament descriptions of this entity. In verses 1-2 and 7, Cush is associated with abundance and fertility, "whose land rivers cut through" (cf. Gen 2:13; Zeph $3: 10$ ) and as belonging to the remote parts of the world, "from along the rivers of Cush" (Esth 1:1; 8:9; Ezek 29:10). The Cushites' physical appearance is "tall and smooth-skinned" (cf. Jer 13:23). Their reputation is "down-treading" (cf. 2 Kgs 19:9; Isa 37:9). This over-focusing on the Cushites in verses 1-2 at the expense of the other group which is mentioned in verse 2 (the messengers)

36 K. Marti, Das Buch Jesaja (Kurzer Hand-Commentar zum Alten Testament 10; Tübingen: J.C.B. Mohr, 1900), 150; Otto Procksch, Jesaja I übersetzt und erklärt (Kommentar zum Alten Testament 9; Leipzig: A. Deichertsche Verlagsbuchhandling D. Werner Scholl, 1930), 241. Marvin A. Sweeney, Isaiah 1-39 with an Introduction to Prophetic Literature (The Forms of the Old Testament Literature 16; Grand Rapids: Eerdmans, 1996), 257; Brevard S. Childs, Isaiah (Old Testament Library; Louisville: Westminster John Knox Press, 2001), 138; Lavik, A People Tall and Smooth-skinned, 182.

37 See Lavik, A People Tall and Smooth-skinned, 156-161, for references.

38 Lavik, 93-94, 185-186. 
functions to create an image of an attractive and invincible power from south. When the motif of Cush is taken up again in verse 7, this serves to envelope the message of Isa 18, but also to develop how the motif is to be understood. In verse 7 , the Cushites are given a new role in the centripetal movement of the nations towards Zion where gifts are brought to YHWH Sebaoth on Zion. ${ }^{39}$ The Hebrew can be understood in the sense that the Cushites themselves are the gift. ${ }^{40}$ The way the motif of Cush is applied in verse 7 underlines the message which has already been communicated $^{41}$ : The Judeans should take notice (vv. 3-4) and seek divine instead of human help (vv. 1-2), as even the powerful Cushites in the end will have to submit themselves under YHWH (v. 7). If the Judeans do not change their plans, the catastrophe will happen (vv. 5-6). The motif of Cush is applied in this specific way to ridicule the Judeans who trust human beings more than YHWH, and to call them to rely on their deity. ${ }^{42}$

To sum up, in my interpretation of the rhetoric of Isa 18, the motif of Cush is used to lure the Judeans. The way the land and people of Cush are described leaves an impression of the Cushites as invincible and exaggerates their position as a potential coalition partner. The vivid description of Cushites and their land in the two first verses of Isa 18 functions to entice the audience into a rhetorical trap. The message which is communicated throughout the text of Isa 18 therefore is that the Judeans should trust YHWH and not human powers (the strong and attractive potential alliance partner Cush). In verse 7, the description of verses 1-2 of the Cushites is repeated, but also developed to include their presence at Zion. This inclusio provides the puzzling text with some sense of coherence. The metaphor of the vineyard is usually applied to the people of YHWH throughout the Old Testament. When Isa 18:5-6 describes the tendrils of the wine to be cut down and devoured by beasts and birds of prey, this serves to place the people of YHWH at the centre of attention. Last, the linking of the people of Cush to YHWH Sebaoth on Mount Zion (v. 7) serves to contrast the potential fate of the Judeans - the Cushites are seen in the midst of eschatological events at Mount Zion whereas the Judeans are likened to a damaged vineyard.

\section{CONCLUSION}

The Nigerian biblical scholar David Tuesday Adamo, through his many contributions to the interpretation of the Cush texts, has drawn the attention of the Old Testament guild globally to what can be labelled an African presence in

39 Christopher J.H. Wright, The Mission of God: Unlocking the Bible's Grand Narrative (Downers Grove: IVP Academic, 2006), 484-486.

40 Willem A.M. Beuken, Jesaja 13-27 (Herders Theologische Kommentar zum alten Testament; Freiburg: Herder 2007).

41 For an argument to support this stance, see Lavik, A People Tall and Smoothskinned; "Are the Kushites Disparaged in Isaiah 18?"

42 Lavik, A People Tall and Smooth-skinned; "Are the Kushites Disparaged in Isaiah $18 ? "$ 
the Old Testament. This is timely as traditional historical-critical scholarship has not showed great interest in the texts about Cush.

The application of the literary motif throughout the Old Testament shows a predominantly favourable portrayal of Cush and Cushites. In the Law, the references in the creation story, in the family story of Noah and in relation to Moses place Cush and Cushites on the ancient Israelites' geographical and mental map. In the Prophets, the Cushites are also placed on the political map as the texts portrays Cush as a potential alliance partner. Further, individuals from Cush are described in the Prophets as playing a role in the history of the people of YHWH. In the Writings, Cush is associated with wealth and military abilities and is also referred to as the south-western border of the world. In addition, Cush and Cushites are positioned on the eschatological map as they are linked to future events that would take place on Zion.

The biblical writers use the reputation of Cush as a powerful rhetorical device in their messages to the people of YHWH. As a piece of persuasive artistry, Isa 18 functions to ridicule the Judean leaders who actively seek an alliance partner in the powerful Cush. What seems to be a word of judgement against the Cushites is shown to be a message of disparagement of the people of YHWH. ${ }^{43}$ The underlying message passed on to the ancient Judean audience is thus: Even the attractive and strong potential alliance partner Cush (Isa 18: 1-2) will have to submit herself under YHWH (v. 7) and the people of YHWH should take note, be quiet and seek help from YHWH and not from any human power, not even the strong Cushites (vv. 3-6).

\section{E BIBLIOGRAPHY}

Adamo, David T. "The Place of Africa and Africans in the Old Testament and Its Environment." PhD thesis, Baylor University: Waco, 1986.

. "The Black Prophet in the Hebrew Bible." Journal of Arabic and Religious Studies 4 (1987): 1-8.

. "The African Wife of Moses: An Examination of Numbers 12:1-9." Africa Theological Journal 18 (1989): 230-237.

. "Amos 9:7-8 in an African Perspective." Orita 24 (1992): 76-84.

. "Ethiopia in the Bible." African Christian Studies 8 (1992): 51-64.

. "The Table of Nations Reconsidered in African Perspective (Genesis 10)." Journal of African Religion and Philosophy 2 (1993): 138-143.

. Africa and Africans in the Old Testament. International Scholars Publications. San Francisco: Christian University Press, 1998.

Anderson, Roger W. "Zephaniah ben Cushi and Cush of Benjamin." Pages 45-70 in The Pitcher is Broken: Memorial Essays for Gösta W. Ahlström. Edited by S.W. Holloway and L.K. Handy. Sheffield: Sheffield Academic Press, 1995.

43 Lavik, A People Tall and Smooth-skinned; Lavik, "Are the Kushites Disparaged in Isaiah 18?" 
Aubin, Henry T. The Rescue of Jerusalem: The Alliance of Hebrews and Africans in 701 BC. Toronto: Anchor Canada, 2003.

Balogh, Csaba. The Stele of YHWH in Egypt: The Prophecies of Isaiah 18-20 Concerning Egypt and Kush. Oudtestamentische Studien 60. Leiden: Brill, 2011.

Beuken, Willem A.M. Jesaja 13-27. Herders Theologische Kommentar zum alten Testament Freiburg: Herder 2007.

Brueggemann, Walter. Isaiah 1-39. Louisville: Westminster John Knox Press, 1998.

Burrell, Kevin. Cushites in the Hebrew Bible: Negotiating Ethnic Identity in the Past and Present. Biblical Interpretation Series 181. Leiden: Brill, 2020.

Childs, Brevard S. Isaiah and the Assyrian Crisis. Studies in Biblical Theology, Second Series 3. London: SCM Press, 1967.

. Isaiah. Old Testament Library. Louisville: Westminster John Knox Press, 2001.

Cook, Paul M. A Sign and a Wonder: The Redactional Formation of Isaiah 18-20. Supplements to Vetus Testamentum 147. Leiden: Brill 2011.

Even-Shoshan, Abraham. A New Concordance of the Bible. Jerusalem: Kiryat-Sepher Publishing House [Hebrew], 1983.

Hays, Daniel J. "The Cushites: A Black Nation in Ancient History." Bibliotheca sacra 153 (1996): 270-280.

Hidal, S. "The Land of Cush in the Old Testament." Svensk exegetisk årsbok 41-42 (1977): 97-106.

Holter, Knut. "Africa in the Old Testament." Pages 93-106 in Yahweh in Africa: Essays on Africa and the Old Testament. Edited by Knut Holter. New York: Peter Lang, 2000.

. "Is Israel Worth More to God than Cush? An Interpretation of Amos 9:7." Pages 115-125 in Yahweh in Africa: Essays on Africa and the Old Testament. Edited by Knut Holter. New York: Peter Lang, 2000.

. "Should Old Testament Cush be Rendered 'Africa'?" Pages 107-114 in Yahweh in Africa: Essays on Africa and the Old Testament. Edited by Knut Holter. New York: Peter Lang, 2000.

. "'A Negro, Naturally a Slave.' An Aspect of the Portrayal of Africans in Colonial Old Testament Interpretation." Old Testament Essays 21/2 (2008): 373-382.

. "Does a Dialogue between Africa and Europe Make Sense?" Pages 69-80 in African and European Readers of the Bible in Dialogue. Edited by Hans de Wit and Gerald O. West. Leiden: Brill, 2008.

Høyland, M. "An African Presence in the OT? David Tuesday Adamo's Interpretation of the OT Cush Passages." Old Testament Essays 11/1 (1998): 50-58.

Lavik, Marta Høyland. A People Tall and Smooth-skinned: The Rhetoric of Isaiah 18. Supplements to Vetus Testamentum 112. Leiden: Brill, 2007.

. “Afrika i Det gamle testamentet." Pages 173-181 in Med Kristus til jordens ender: Festskrift til Tormod Engelsviken. Edited by K.O. Sannes, Trondheim: Tapir akademisk forlag, 2008.

. “På den tid skal dei koma med gåver til Herren over hærskarane, frå det høgvaksne glinsande folket': Afrikanske og afrikansk-amerikanske tolkingar av GT-tekstar om Kusj." Pages 155-169 in Jerusalem, Samaria og jordens ender: 
Bibeltolkninger tilegnet Magnar Kartveit, 65 år, 7. Oktober 2011. Edited by K. Holter and J. Ådna, Trondheim: Tapir akademisk forlag, 2011.

. "Are the Kushites Disparaged in Isaiah 18? Kush Applied as a Literary Motif in the Hebrew Bible." Journal of Hebrew Scriptures 19/7 (2019): 17-43. Cited 15 October 2020. Online: http://www.jhsonline.org/Articles/article_253.pdf

Lee, J. A Redactional Study of the Book of Isaiah 13-23. Oxford: Oxford University Press, 2018.

Levenson, Jon D. Sinai and Zion. An Entry into the Jewish Bible. Minneapolis: Winston Press, 1985.

Lokel, P. "Previously Unstoried Lives: The Case of Old Testament Cush and Its Relevance to Africa." Old Testament Essays 19/2 (2006): 525-537.

. "The Importance and Challenges of Finding Africa in the Old Testament: The Case of the Cush Texts." PhD thesis, Pretoria: University of South Africa, 2006.

Marti, K. Das Buch Jesaja. Kurzer Hand-Commentar zum Alten Testament 10. Tübingen: J.C.B. Mohr, 1900.

Procksch, Otto. Jesaja I übersetzt und erklärt. Kommentar zum Alten Testament 9. Leipzig: A. Deichertsche Verlagsbuchhandling D. Werner Scholl, 1930.

Rice, Gene. "The African Roots of the Prophet Zephaniah." The Journal of Religious Thought 36 (1979): 21-31.

Sadler, Rodney S. Can a Cushite Change His Skin? An Examination of Race, Ethnicity, and Othering in the Hebrew Bible. Journal for the Study of the Old Testament Supplement Series 425. New York: T \& T Clark, 2005.

Smith, R. "A New Perspective on Amos 9:7a." Journal of the Interdenominational Theological Center 22 (1994): 36-47.

Speiser, E.A. "The Rivers of Paradise." Pages 473-485 in Festschrift Johannes Friedrich zum 65. Geburtstag am 27. August 1958 gewidmet. Edited by R. von Kienle and A. Moortgat et al. Heidelberg: Carl Winter Universitätsverlag, 1959.

Stordalen, Terje. Echoes of Eden: Genesis 2-3 and Symbolism of the Eden Garden in Biblical Hebrew Literature. Contributions to Biblical Exegesis and Theology 25. Leuven: Peeters, 2000.

Sweeney, Marvin A. Isaiah 1-39 with an Introduction to Prophetic Literature. The Forms of the Old Testament Literature 16. Grand Rapids: Eerdmans, 1996.

Van Heerden, Willie. "Finding Africa in the Old Testament: Some Hermeneutical and Methodological Considerations." Old Testament Essays 19/2 (2006): 500-524.

Watson, Duane F., ed. Persuasive Artistry: Studies in New Testament Rhetoric in Honor of George A. Kennedy. Journal for the Study of the New Testament Supplement Series 50. Sheffield: Sheffield Academic Press, 1991.

Wright, Christopher J.H. The Mission of God: Unlocking the Bible's Grand Narrative. Downers Grove: IVP Academic, 2006.

Prof. Marta Høyland Lavik, The Research Group for Nursing- and Healthcare Science, Stavanger University Hospital, Helse Stavanger HF, Postboks 8100, 4068 Stavanger, Norway and Faculty of Theology, Stellenbosch University, South Africa. ORCID: https://orcid.org/0000-0003-0569-5123 